\title{
О НЕКОТОРЫХ РАЗНОВИДНОСТЯХ ЯЗЫКОВОЙ ИГРЫ В КИНОДИСКУРСЕ
}

В статье даётся описание и анализ различных видов языковой игры (ЯИ) на лексико-семантическом уровне в кинематографическом дискурсе на материале телесериалов производства Великобритании и США последних двух десятилетий. $B$ статье описаны выявленные особенности языковой игры в исследуемом материале, как в плане создания, так и в плане функиионирования. Выделены следуюшие приёмы ЯИ: двойная актуализачия и буквализачия высказывания, $а$ также языковая игра с привлечением расширенной метафоры, зевгмы и ЯИ на эффекте обманутого ожидания.

Ключевые слова: языковая игра, кинематографический дискурс, эффект обманутого ожидания, зевгма, метафора.

The article contains a description and analysis of various cases of word play at the lexical-semantic level used in the British and American TV series of the last two decades. The article describes characteristic features of word play in reference both to form and functioning. The examples of forms of word play include literalization of the meaning of an utterance, double actualization of meaning, as well as word play based on the use of sustained metaphor and zeugma, word play involving the effect of defeated expectancy.

Key words: word play, cinematographic discourse, defeated expectancy, zeugma, metaphor.

Сферы использования языковой игры разнообразны и не имеют ограничений, исследование же ЯИ в малоизученных областях её использования представляется наиболее перспективным.

Под кинодискурсом мы вслед за А.Н. Зарецкой понимаем связный текст, являющийся вербальным компонентом фильма, в совокупности с невербальными компонентами 
аудиовизуальным рядом и другими значимыми для смысловой завершённости фильма экстралингвистическими факторами. Можно выделить различные невербальные средства: рисунки, жесты, мимику, которые важны при создании и восприятии кинофильма, культурно-исторические фоновые знания адресата, а также экстралингвистический контекст - обстановка, время и место, к которым относится фильм [Зарецкая 2010].

Под языковой игрой мы понимаем проявление лингвокреативного мышления, которое основывается на ассоциативных механизмах и проявляется в способности говорящих «к намеренному использованию нестандартного языкового кода в разных ситуациях речевой деятельности» [Гридина 2008: 4] и служит средством самовыражения языковой личности [Нухов 2012: 169]. Как отмечает известный американский антрополог, лингвист и натуралист Питер Фарб, речевое поведение человека - это взаимодействие, игра, в которой оба собеседника подсознательно следуют правилам говорения их языковой общности. Точно так же, как в традициях трансформационной грамматики считается, что личность интуитивно следует грамматическим правилам родного языка, так же интуитивный подход распространяется и на умение использовать язык исходя из коммуникационной ситуации [Farb 1976: 4]. Тем самым, при использовании языковой игры говорящий не задумывается о нормах языка и не ставит конкретных целей воздействия на адресата, а скорее руководствуется стремлением выразить свои мысли и чувства, «облекает в языковые формы свой внутренний мир» [Нухов 2017: $16]$.

Языковая игра на лексико-семантическом уровне является наиболее частотной в кинематографическом дискурсе ввиду многообразия её видов (см. работу [Войцех 2021]). Перейдём непосредственно к рассмотрению различных видов языковой игры в телесериалах.

\section{Обман ожиданий}

LORD BRANNOX: Everyone knows who you are. Do you know how many times I read your delightful "Man Behind the Scenes?"

VOIELLO: No.

LORD BRANNOX: Once.

("The New Pope" - телесериал, s01e03) 
В данном примере из телесериала «Новый папа» использован классический приём обмана ожидания, строящийся на коммуникативном опыте человека. Зная, что обычно после подобной фразы упоминается достаточно значительное число, мы подсознательно ждём соответствующего продолжения, что и позволяет «играть» с нашими ожиданиями. Представленный диалог - первое личное знакомство зрителя с лордом Брэнноксом, главным героем телесериала. И для того, чтобы представление героя оказалось убедительным, чтобы в глазах зрителя закрепился его образ как человека остроумного и непредсказуемого, используется приём обмана ожиданий. Из дальнейшего контекста становится ясно, что «однажды» он прочёл книгу лишь потому, что она была слишком хороша, и он до глубины проникся написанным, однако первоначальный эффект потрясения работает как для зрителя, так и для собеседника, Войелло. Тем самым, происходит двойной обман ожиданий: в первый раз, когда мы слышим «однажды» вместо внушительного числа, и второй когда мы понимаем, что в основе высказывания героя лежит не ирония, а искусно построенная метафора.

\section{Расширенная метафора}

SOFIA: People are asking, "Is this Pope porcelain or steel?" JOHN PAUL III: Why not something in between? Fiberglass. ("The New Pope" - телесериал, s01e04)

В данном случае перед нами сложный пример использования расширенной метафоры, основанной на двусмысленности. Прежде чем прокомментировать приведённый пример, следует отметить, что обычно метафору относят к видовым понятиям двусмысленности в том случае, если в коммуникации происходит процесс, обратный метафоризации её буквализация, актуализация изначального смысла [Филиппов, Романова 2002: 96]. Однако в нашем случае происходит другой процесс - расширение метафоры, и именно выбор лексической единицы для продолжения образного сравнения позволяет нам отнести данный пример к категории двусмысленности. Действие сериала разворачивается в Ватикане вокруг высших чинов католической церкви, и в приведённом диалоге мы видим отрывок разговора недавно избранного Папы Иоанна Павла III и маркетолога Ватикана Софии. Она обеспокоена тем, что общественность не знает, чего ожидать от нового Папы - хрупок 
он как фарфор или твёрд как сталь? На эти опасения Папа с улыбкой отвечает: лучше выбрать что-то среднее, например, стеклопластик. С одной стороны, продолжение метафоры вполне понятно в плане содержания - выбирается материал с характеристиками прочности примерно посередине между фарфором и сталью. С другой стороны, необходимо учитывать исторический контекст. Иоанн Павел известен всему католическому миру своим теоретическим трудом «Золотая середина», в котором он призывает не ударяться в крайности и всегда искать компромисс (“the middle way"). Тем самым, упоминая стеклопластик как что-то среднее между предложенными материалами, герой также отсылает к своему теоретическому труду, что помогает лучше понять его жизненную философию.

\section{Буквализация значения высказывания}

DOCTOR: I could bring down your government with a single word.

HARRIET JONES: You're the most remarkable man I've ever met, but I don't think you're quite capable of that.

DOCTOR: No, you're right. Not a single word. Just six.

("Doctor Who" - телесериал, s02e00)

Данный пример из научно-фантастического телесериала «Доктор Кто» представляет собой разговор между персонажем Доктором, пришельцем с другой планеты и путешественником во времени, и Гарриет Джонс, политиком, которая во время его прошлого визита на Землю стала премьер-министром Великобритании, не без помощи Доктора. Однако власть меняет людей, и теперь мисс Джонс поступает опрометчиво, подвергая опасности жизни тысяч людей. Доктору это не нравится, и, понимая, что частично в этом виноват он сам, он решает исправить ситуацию, лишив её поста. Однако перед этим остроумный Доктор предоставляет Гарриет последний шанс, который может заставить его передумать, но её ответ лишь укрепляет его решимость довести дело до конца. И если в первом случае угроза «лишить её поста одним словом» была лишь метафорой, во второй же реплике Доктор использует ответ Джонс и свою фразу буквально - одним словом он этого не сделает, но шести будет достаточно. Эти шесть слов - «Don't you think she looks tired?", сказанные её помощнику, действительно стоят ей 
поста премьер-министра. Тем самым этот остроумный диалог показывает, что с Доктором лучше не шутить, он в самом деле всесилен.

\section{Двойная актуализация значения высказывания}

GRACE: Want tea?

THOMAS: Tea? No.

GRACE: I have rum.

THOMAS: Actually, tea it is.

GRACE: You want to impress me?

THOMAS: Yes. <...> People look different at home.

GRACE: In what way?

THOMAS: Off guard.

GRACE: Should I be on my guard?

THOMAS: No, I'm a man who drinks tea.

("Peaky Blinders" - телесериал, s01e05)

B нашем материале двойная актуализация значения высказывания, как и его буквализация, является одним из наиболее частотных приёмов создания языковой игры в кинодискурсе. Однако в данном случае приём использован не совсем в стандартном проявлении. Второй из реализуемых планов содержания, метафорический, заложен контекстом ситуации. С одной стороны, Томас действительно пьёт чай в момент разговора. С другой стороны - это иносказательное сообщение для Грейс о том, что ей не стоит его бояться, он не причинит ей вреда. В данном случае пример осложняется ещё и лексическими повторами, что придаёт большую глубину диалогу и глубже раскрывает характер отношений между героями.

\section{Зевгма}

OSWALD MOSLEY: Next time bring only an open mind and a cigar to celebrate our union.

("Peaky Blinders" - телесериал, s05e05)

Зевгма сравнительно нечасто встречается среди случаев языковой игры в кинодискурсе, однако контекст её употребления позволяет сделать вывод о том, что она используется исключительно в устах персонажей остроумных, уверенных в себе, желающих показать себя хозяевами положения. Иными словами, зевгма может служить индикатором высокого уровня интеллекта персонажей, в том числе и языкового. Фраза в данном примере адресована главному герою Томасу Шелби, который не 
хочет соглашаться на условия сотрудничества про-фашистски настроенного Мосли. Однако пока ему нечего противопоставить Освальду, поэтому в диалоге явное преимущество закрепляется за Освальдом, что передаётся через его реплики диалога. Использование зевгмы осложняется ещё и метафорическим смыслом, вкладываемым в образ сигары как символа заключения перемирия.

Таким образом, языковая игра в кинодикурсе может существовать в самых разнообразных формах. Разные виды ЯИ нередко переплетаются для создания ещё более выразительного и запоминающегося образа. Зачастую в языковой игре также в том или ином виде присутствует метафорический компонент, а сама игра в основном работает на создание образа персонажей, передачу их эмоций, а также на демонстрацию интеллектуального превосходства героя.

\section{ЛИТЕРАТУРА}

1. Войцех К.Д. Языковая игра в кинематографическом дискурсе: лексико-семантический уровень // Вестник Башкирского университета, 2021. Т. 26, №1. - С. 235-240.

2. Гридина Т. А. Языковая игра в художественном тексте: Монография: Урал. гос. пед. ун-т. Екатеринбург, 2008. - 165 c.

3. Зарецкая А.Н. Особенности реализации подтекста в кинодискурсе: автореф. дисс. … канд. филол. наук. Челябинск: Челяб. гос. ун-т, 2010. - 22 с.

4. Нухов С. Ж. Окказиональное именное словообразование английского языка сквозь призму языковой игры. Уфа: РИЦ БашГУ, 2017. - 230 с.

5. Нухов С. Ж. Языковая игра: возможные подходы и трактовки явления // Вестник Башкирского университета, 2012. № 1. Т. 17. - С. 165-170.

6. Филиппов А.В., Романова Н.Н. Публичная речь в понятиях и упражнениях: Справочник: Учеб. пособие для студ. высш. учеб. заведений. - М.: Издательский центр «Академия», 2002. - 160 c.

7. Farb P.Word Play: What Happens When People Talk. - N.Y.: Bantam Books, 1976. - 421 p.

(c) Войцех К.Д, 2021 г. 